\title{
The validation of the servant leadership scale
}

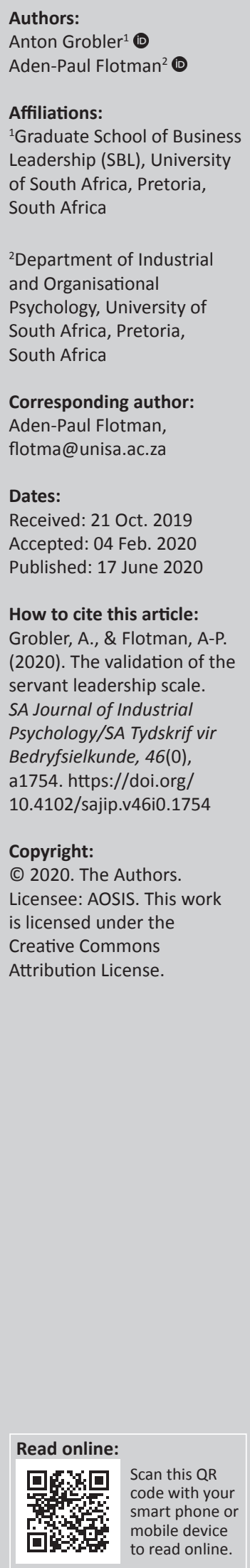

Orientation: When opening any newspaper across the globe, the dominant narrative appears to be a driving obsessive preoccupation with how leaders consciously and often unconsciously create a working environment that serves their personal interests, fears and desires. This treacherous preoccupation inevitably influences a person's leadership style and leadership agenda and therefore stands in direct opposition to what come to be known as servant leadership.

Research purpose: The purpose of this article was to validate the 7-item servant leadership questionnaire (SLQ7) within the South African context.

Motivation for the study: Owing to the emergence of the notion of servant leadership in South Africa, there exists a need for a valid measure of servant leadership in an organisational setting. Many leadership instruments developed in foreign countries (also the SLQ) are merely used by leadership scholars without assessing its transferability to that specific context, and this poses scientific and ethical challenges.

Research approach/design and method: A convenience sample of 1764 respondents, employed in both private and public sectors (employed in 31 different organisations), relatively well representative of the South African workforce in general, was used for this study.

Main findings: An exploratory and confirmatory factor analysis yielded a one-factor solution of servant leadership that has acceptable psychometric and fit properties. The instrument was further found to have adequate convergent validity (compared with cognate leadership and organisational behaviour constructs).

Practical/managerial implications: The SLQ7 version was found to be suitable for use across different samples, including the private and public sectors, and could be used with confidence within the South African context.

Contribution/value-add: This study's contribution to science, practice and the community is based on the importance of the servant leadership construct when leading people, specifically in the South African (and African) context. The study confirms the servant leadership scale as a valid and reliable measuring instrument in the South African context and, determines how servant leadership impacts organisational behaviour within the South African and African context.

Keywords: leadership; servant leadership; validation; servant leadership scale; Afrocentric.

\section{Introduction}

\section{Background of and rationale for the study}

As leaders move up the corporate ladder, they accumulate immense power, wide-reaching influence and significant authority. Leaders are therefore confronted with the seductive lure of using this influence for personal benefits, whether in the form of where resources are allocated, the movement of organisational resources that emanate from decision-making or the conscious and unconscious management of organisational dynamics (Diamond, 2016; Long, 2008; Sher, 2010). The impetus for this article stems from our experience and interaction with reports on corporate criminality and the depressingly corrosive impact of such unscrupulous behaviour on employee well-being and engagement. There has been a recent resurgence of servant leadership (Ebener \& O'Connell, 2010; Mahembe \& Engelbrecht, 2013; Parris \& Peachey, 2013; Sendjaya \& Sarros, 2002; Thao \& Kang, 2020; Van Dierendonck, 2011). This resurgence has resulted in muchneeded ethical grounding (Savage-Austin \& Honeycutt, 2011), particularly in the face of increasing levels of organisational perversity (Avey, Wernsing, \& Palanski, 2012; Long, 2008; MitongaMonga, Flotman, \& Cilliers, 2016), and unethical behaviour (Vansina, 2014; Walumbwa \& Schaubroeck, 2009). It has been suggested that servant leadership has a contribution to make to societal demands for integrity, transparency and consequence management (Dennis, KinzlerNorheim, \& Bocarnea, 2010; Liden, Wayne, Zhao, \& Henderson, 2008). 
Leadership orientation often determines the direction leaders take and their ultimate destination. Servant leadership is essentially follower-orientated (Parris \& Peachey, 2013; Van Dierendonck, Stam, Boersma, De Windt, \& Alkema, 2014). Servant leaders selflessly empower others by investing in them and by being mindful of how their influence could have a positive impact on their followers. Studies have shown that servant leadership has a positive impact on follower well-being, engagement and performance (Van Dierendonck \& Nuijten, 2011). Empirical studies further suggest that servant leadership has predictive value at the individual, group and organisational levels. For example, at the individual level, servant leadership is positively related to outcomes, such as self-efficacy, employee engagement, organisational citizenship behaviour, turnover intention and organisational commitment (Liden et al., 2008; Van Dierendonck et al., 2014; Walumbwa, Hartnell, \& Oke, 2010). At the group and organisational levels, it is linked to team performance and organisational performance, respectively (Peterson, Galvin, \& Lange, 2012).

\section{Research purpose}

In spite of the existence of previous empirical studies, there remains a need for a validated servant leadership scale across multiple cultures (Van Dierendonck \& Nuijten, 2011), particularly within the African context (Geldenhuys \& Veldsman, 2010; Mahembe \& Engelbrecht, 2013). There also does not seem to be a consensus in terms of the conceptualisation of servant leadership (Sun \& Wang, 2009), which makes the comparison of empirical studies more cumbersome (Bass, 2000; Farling, Stone, \& Winston, 1999; Sendjaya \& Sarros, 2002). A notable empirical observation is the positive incremental variance in recent studies, which has given empirical studies on servant leadership significant legitimacy (Ehrhart, 2004; Liden et al., 2008; Peterson et al., 2012; Van Dierendonck et al., 2014). Subsequently, the purpose of this study was to assess the construct validity of the 7-item servant leadership questionnaire (SLQ7) within the unique South African context, to provide an instrument that could be used with confidence (and ethically) by leadership scholars in South Africa. This will enable scholars to compare studies and findings across different research populations, based on a standardised servant leadership instrument.

\section{Potential value added by the study}

The unique contribution of this study is that it firstly confirms the servant leadership scale as a valid and reliable measuring instrument in the South African context and, secondly, determines how servant leadership impacts organisational behaviour within the South African context. Servant leadership is different from other dominant leadership styles, for example, authentic leadership, leader-member exchange (LMX) theory and Afrocentric leadership. It is notable that outside the United States, Europe and the Asia-Pacific region, there appears to be a paucity of research on servant leadership
(Ragnarsson, Kristjansdottir, \& Gunnarsdottir, 2018; Thao \& Kang, 2020; Van Dierendonck et al., 2014). In addition, studies have shown that servant leadership has different meanings, depending on socialisation and national context (Parris \& Peachey, 2013).

\section{Literature review}

\section{Conceptualisations of servant leadership}

Pertinent evolutionary perspectives: The servant leadership theory, which has emanated from the work of Greenleaf (1977), appears to go against the grain of the basic human desire of serving self-interests first. It does so by advocating that the primary motive of the leader should be to serve others first by placing the well-being of followers (i.e. their needs, interests and aspirations) above that of the leader (Dansereau, Graen, \& Haga, 1975; Greenleaf, 1977; Laub, 2004). The servant leader is imbued with an authentic concern to be at the service of his or her followers. Thus, service to others is not rendered by default but by design and conscious choice (Greenleaf, 1977). Servant leadership has a strong focus on the development of followers and brings with it a deep sense of ethics and morality (Wong \& Page, 2003). The essence of servant leadership is to serve the good of the whole, demonstrating a genuine care for others, trustworthiness and a well-developed sense of integrity (Parris \& Peachey, 2013). Thus, in Greenleaf's (1977) words:

The servant leader is a servant first... It begins with the natural feeling that one wants to serve, to serve first. Then conscious choice brings one to aspire to lead...to make sure that other people's highest-priority needs are being served... (p. 13)

It is this primary intent, along with its motivational drive, that distinguishes servant leadership from other leadership approaches (Sendjaya \& Sarros, 2002; Sendjaya, Sarros, \& Santora, 2008). Servant leadership puts stewardship at the centre of leadership (Block, 1993) and recognises the responsibility to serve, particularly those marginalised by the organisational system, as the primary responsibility of the servant leader (Graham, 1991). Another major contribution comes from Spears $(2002,2010)$, whose work was built on Greenleaf's (1977) conceptual framework. Spears (2010) identified 10 characteristics of a servant leader, namely, listening, empathy, healing, awareness, persuasion, conceptualisation, foresight, stewardship, commitment to the growth of people and building community. Patterson (2003) later developed the component 'constructs' (values), which, in a sense, shapes the attitudes, behaviours and characteristics of a typical servant leader. She defined servant leaders as 'those who serve with a focus on the followers, whereby the followers are the primary concern and the organisational concerns are peripheral' (Patterson, 2003, p. 81). The seven constructs in Patterson's (2003) model comprise Agápao love, humility, altruism, vision, trust, empowerment and service. The definition of servant leadership by Laub (2004) has also been used extensively in the literature (Crippen, 2004; Crippen \& Wallin, 2008; Sturm, 
2009) and is stated simply as 'to place the good of those led over the self-interest of the leader' (Laub, 1999, p. 81). The original scale developed by Liden et al. (2008) consisted of seven dimensions: emotional healing, creating value for the community, conceptual skills, empowering, helping subordinates grow and succeed, putting subordinates first and behaving ethically. A more comprehensive discussion of this scale is provided below. A significant contribution by Sendjaya et al. (2008) is that servant leaders should view themselves primarily as stewards who are entrusted with the development and empowerment of their followers on their journey to achieving their full potential. Van Dierendonck and Nuijten (2011) purported that servant leadership is also about providing direction. Thus, these latter two authors further claimed that their definition included the critical aspects of accountability and courage and measured the leader-follower relationship from the perspective of the follower (Van Dierendonck \& Nuijten, 2011).

It is clear, then, that the focus of earlier studies on servant leadership was on identifying themes to operationalise the construct. Table 1 reflects the evolution of these dominant themes.

Thus, the crux of servant leadership is that the leader is follower-focussed, has an altruistic mindset and is imbued with the intent to serve. The outcome of this robust ethical disposition, positive use of influence and follower authorisation is a deeper sense of follower satisfaction, commitment to service and ultimate enhancement of the common good.

Afrocentric leadership perspective: Scholars have defined Afrocentricity differently through the years. The predominant definition seems to be that of Asante (1988, p. 3), who defined it as 'a manner of thought and action in which the centrality of African interests, values, and perspectives predominate'.

TABLE 1: Servant leadership - Dominant evolutionary themes.

\begin{tabular}{|c|c|}
\hline Author & Themes and subthemes \\
\hline Graham (1991) & Inspirational, moral \\
\hline Buchen (1998) & $\begin{array}{l}\text { Self-identity, capacity for reciprocity, relationship } \\
\text { builders, preoccupation with the future }\end{array}$ \\
\hline Spears (1998) & $\begin{array}{l}\text { Listening, empathy, healing, awareness, persuasion, } \\
\text { conceptualisation, foresight, stewardship, commitment, } \\
\text { community-building }\end{array}$ \\
\hline Farling et al. (1999) & Vision, influence, credibility, trust, service \\
\hline Laub (1999) & $\begin{array}{l}\text { Valuing people, developing people, community-building, } \\
\text { displaying authenticity, providing leadership, sharing }\end{array}$ \\
\hline Patterson (2003) & $\begin{array}{l}\text { Agápao love, humility, altruism, vision, trust, } \\
\text { empowerment, service }\end{array}$ \\
\hline $\begin{array}{l}\text { Dennis and } \\
\text { Bocarnea (2005) }\end{array}$ & Empowerment, trust, humility, Agápao love, vision \\
\hline Liden et al. (2008) & $\begin{array}{l}\text { Empowering, helping, subordinates grow and succeed, } \\
\text { putting subordinates first, emotional healing, conceptual } \\
\text { skills, creating value for community, behaving ethically }\end{array}$ \\
\hline Sendjaya et al. (2008) & $\begin{array}{l}\text { Transforming influence, voluntary subordination, } \\
\text { authentic self, transcendental spirituality, covenantal } \\
\text { relationship, responsible morality }\end{array}$ \\
\hline $\begin{array}{l}\text { Van Dierendonck and } \\
\text { Nuijten (2011) }\end{array}$ & $\begin{array}{l}\text { Empowerment, humility, standing back, authenticity, } \\
\text { forgiveness, courage, accountability, stewardship }\end{array}$ \\
\hline
\end{tabular}

This perspective thus nurtures a form of African consciousness and emphasises the centrality of the African experience and African phenomena. The purpose of this movement has been articulated as an attempt to bring together the oftendisjointed strands of African and African-American studies into a 'unified discipline, with ideological and intellectual goals, political purpose, and a set of commonly understood methods and theories' (Early, Moses, Wilson, \& Lefkowitz, 1994, p. 46). This movement has provided impetus for the call for more empirical studies on leadership in Africa (Afrocentric leadership) (Fourie, Van der Merwe, \& Van der Merwe, 2017). In spite of cautions not to see Afrocentric leadership as a single, generic construct (Nkomo, 2011), it has been defined as a leadership style, which stresses the leadership role of being a servant to the community, ensuring that there is fairness and harmony, promoting participation, collective decision-making, community-building and the common good (Mbigi, 2000; Mulemfo, 2000; Van Rensburg, 2013). This form of leadership is thus community-orientated, seeing all aspects of life as being nurtured into a harmonious community, and collective strength and potential being harnessed in the interest of the community. Central to this community orientation is the concept of $u b u n t u$, which means that I can only be a person through others (Mbiti, 1989). From an organisational perspective, ubuntu is based on the following four basic principles: Morality - organisations can reach maximum potential only by being connected to their moral base; interdependence - wealth creation is achieved when interdependence is acknowledged; spirit of man - all employees are entitled to unconditional respect and human dignity; and totality - every contribution by every member in the organisation must be acknowledged and appreciated (Mbigi, 2000). These principles highlight the importance of relationships and that leaders should be servants and therefore always act in the interest of the common good.

\section{Servant leadership in relation to authentic leadership}

Authentic leadership is conceptualised as 'an important organizational resource' (Laschinger \& Fida, 2014, p. 20) and is reflective of leaders who are 'deeply aware of their values and beliefs; they are self-confident, genuine, reliable, and trustworthy, and they focus on building followers' strengths' (Ilies, Morgeson, \& Nahrgang, 2005, p. 374). Similar to servant leaders, authentic leaders focus on the positive selfdevelopment of their followers by drawing upon and promoting 'positive psychological capacities and a positive ethical climate' (Walumbwa, Avolio, Gardner, Wernsing, \& Peterson, 2008, p. 94). Furthermore, authentic leaders strive to protect their followers' resources, whereas servant leaders emphasise the building of a serving culture that encourages followers to prioritise the needs of others (Liden et al., 2008).

\section{Servant leadership in relation to leader-member exchange}

The leader-member exchange theory is another popular leadership theory. The essence of this relationship-based approach to leadership, as opposed to authentic leadership or servant leadership, is that the relationship between leader 
and follower is perceived as an exchange relationship (Graen \& Uhl-Bien, 1995; Ilies, Nahrgang, \& Morgeson, 2007; Lunenburg, 2010). Perceived similarities between the leader and the follower, and the subsequent formation of self-schemas, could lead to a greater liking of followers and an enhanced quality of leader-member exchanges (Engle \& Lord, 1997). Leaders thus use their position and power to nurture exchange relationships with followers, often on a face-to-face basis. They respond to their followers' individual needs, resulting in the fostering of trust, a partnering mentality and mutual respect for each other's capabilities (Graen \& Uhl-Bien, 1995). However, it has been suggested that LMX has not been able to articulate the specific resources that leaders bring to the dyadic relationship (Braun \& Nieberle, 2017). Furthermore, servant leadership extends beyond LMX in that the leader does not simply support followers but also attends to the personal needs of followers, both inside and outside the organisation (Liden et al., 2008).

\section{Servant leadership in relation to Afrocentric leadership}

In a study conducted by Geldenhuys and Veldsman (2010), servant leadership was linked to Afrocentric leadership, which is contrary to the typical Western paradigm of leadership. As with servant leadership, this paradigm focusses on teamwork, participation and collective brotherhood and sisterhood (Grobler \& Singh, 2018; Ngambi, 2004; Nkomo, 2011; Van Rensburg, 2013), which is fundamentally different from the individualistic, competitive Western leadership perspective (Chawane, 2016; Geldenhuys \& Veldsman, 2010; Yawson, 2017). The Afrocentric worldview perceives work as an integral part of life, and a meaningful life implies engaging in work activities that are in the interest of the community. Similar to Afrocentric leadership, authentic leaders are preoccupied with the collective, group outcomes (Banks, McCauley, Gardner, \& Guler, 2016; Steffens, Mols, Haslam, \& Okimoto, 2016) through value-based actions. Purposeful organisational work, therefore, entails being at the service of one's colleagues and the organisation as a whole, which is nothing less than servant leadership. Both Afrocentric and authentic leadership styles seem to share a common antecedent, which is the galvanisation of collective interest (Steffens et al., 2016).

\section{Measurement of servant leadership}

Several measures exist to assess the perception of the presence and magnitude of servant leadership within an organisational context. However, the scale developed by Liden et al. (2015) a shortened 7-item version (SLQ7) of the 28-item instrument by Liden et al. (2008) (SLQ28), has been identified for validation within the South African context. The decision was made because of the rigour employed by Van Dierendonck and Nuijten (2011) in the development of the original 28-item instrument, and the fact that the 7-item instrument reported validity results similar to those of the longer version (Liden et al., 2015). The original 28-item scale comprised seven dimensions, of which a number of items were taken from the servant leadership scales in Barbuto and Wheeler (2006), Ehrhart (2004) as well as Page and Wong (2000). This longer version of the instrument measures servant leadership characteristics in relation to followers, the organisation as a whole and the community. The original longer version of the instrumentmeasured servantleadership as a multidimensional construct (Van Dierendonck \& Nuijten, 2011). It comprised, according to Liden et al. (2008), the following seven dimensions: (1) emotional healing, which refers to the degree to which the leader cares about the personal problems and wellbeing of his or her followers; (2) creating value for the community, which entails the involvement of the leader in helping the community around the organisation and encouraging active participation in the community; (3) conceptual skills, which refers to the degree to which the leader is competent in solving work problems and understanding the goals of the organisation; (4) empowering, which entails the degree to which the leader entrusts followers with autonomy, responsibility and decision-making; (5) helping subordinates grow and succeed, which captures the extent to which the leader is able to help followers reach not only their full potential but also to succeed in their careers; (6) putting subordinates first, which reflects the degree to which the leader prioritises the needs of others as opposed to his or her own needs; and (7) behaving ethically, which implies being honest, trustworthy and a model of integrity. Four items measure each dimension. According to Liden et al. (2008), servant leadership can be described as a combination of its dimensions - in other words, it is a construct that comprises the sum of its dimensions with each of the dimensions reflecting a specific aspect of leadership behaviour. It was for this reason that Liden et al. (2015) included seven items in SLQ7 that encapsulate all seven dimensions assessed in the full 28-item version of the servant leadership scale. One limitation of the SLQ28 identified by Liden et al. (2015) is its length. It is for this reason that the SLQ7 was developed (and included in this study), measuring servant leadership as a global (or unidimensional) construct. The items read:

'My leader can tell if something work-related is going wrong.' (SLQ71)

'My leader makes my career development a priority.' (SLQ72)

'I would seek help from my leader if I had a personal problem.' (SLQ73)

'My leader emphasises the importance of giving back to the community.' (SLQ74)

'My leader puts my best interests ahead of his or her own.' (SLQ75)

'My leader gives me the freedom to handle difficult situations in the way that I feel is best.' (SLQ76)

'My leader would NOT compromise ethical principles in order to achieve success.' (SLQ77)

Liden et al. (2015) reported acceptable reliabilities 0.80, 0.81 and 0.89 across three independent samples for SLQ7. Acceptable confirmatory factor analysis (CFA) results were also reported. Criterion-related validities for SLQ7 were found and were, interestingly enough, very similar to the SLQ28. The decision to use the shortened instrument is congruent with the view of Credé, Harms, Niehorster and Gaye-Valentine (2012), as they suggested that the use of a 
shorter instrument may increase the integrity of the measurement, as it reduces the strain on the respondent's attention span when reading and answering the items. This is probably more profound in a population that does not speak English as their first language.

The instrument developers, Liden et al. (2015), acknowledged that their studies were mainly carried out with data collected in the United States, China and Singapore, and they recommended further studies, using the instrument in other parts of the world, to include samples from culturally diverse countries. In this instance, the overall sample was from the South African workforce, a population viewed as unique in terms of various aspects, including its history, culture and diversity (including language diversity). In summary, the purpose of this article was to assess SLQ7 in terms of various forms of construct validity, and to cross validate it by utilising multiple independent samples within the South African context.

\section{Research design \\ Research approach}

This study employed a typical empirical paradigm using a cross-sectional design and quantitative analysis.

\section{Research participants}

The population of the study is the South African workforce employed in organisations with 60 or more employees. The sample comprised employees of 31 organisations (conveniently selected in terms of access), with 60 employees per organisation selected randomly, thus totalling to 1860 respondents. Only valid responses (without any missing values) are reported.

The final data set comprised 1764 respondents. The study was multi-sectorial, with close to $52 \%$ of the respondents being from the private sector and $48 \%$ from the public sector. The representation of gender groups was higher for males at $51 \%$, compared to $49 \%$ for females. The mean age of the respondents was 36.47 years (standard deviation $[S D]=8.87$ ), and the mean tenure in the specific organisation was 7.50 years $(\mathrm{SD}=7.28)$. In terms of qualifications, $38 \%$ indicated that they had a bachelor's degree or diploma, followed by respondents with a higher degree (35\%) and matric (21\%). It thus seems that the respondents, in general, were mature, experienced and educated - all necessary attributes for respondents required to provide their opinions about their perceptions of leadership in their organisations (Grobler \& Singh, 2018).

\section{Research procedure}

Data were collected by means of SLQ7 (and related instruments that are discussed later; all these instruments are self-administered, paper and pencil instruments). The 31 co-researchers administered it at their respective organisations and were responsible for the capturing of responses in a pre-developed, protected spreadsheet. The overall data set was compiled through the consolidation of all co-researchers' input.

\section{Statistical analysis}

The statistical analysis was performed using the Statistical Package for the Social Sciences (SPSS 25), supported by SPSS Amos (Analysis of Moment Structures, version 25) (IBM, 2017).

\section{Data screening}

The data set was first cleaned via case screening, followed by variable screening to ensure that there were no missing values in the data set. The data set was further inspected for unengaged responses by running an $\mathrm{SD}$ and inspection of cases with $\mathrm{SD}<$ 0.50. From the data-cleaning process, it was deduced that the missing values were very sparse (less than $5 \%$ of the cases were deleted) and were, therefore, not considered to be a main contributor to any bias. The variables were further screened by means of Kurtosis and the Central Limit Theorem to gather information about the distribution of the data.

\section{Exploratory factor analysis}

The first step of the factor analysis was to evaluate the appropriateness of the sample size to conduct an exploratory factor analysis (EFA). The item-to-respondent ratio of \pm 1 :20 was regarded as acceptable according to Meyers, Gamst and Guarino (2013). Secondly, the inter-correlations between items were inspected using Bartlett's test of sphericity (Hair, Black, Babin, \& Anderson, 2010). With this test, the statistics generated should be significant $(p<0.05)$ for an EFA to be considered an appropriate technique (Hair et al., 2010). Thirdly, the Kaiser-Meyer-Olkin (KMO) measure was used to quantify whether the items correlated sufficiently to determine whether a factor analysis could be performed. The minimum level set for this statistic was 0.60 (Tabachnick \& Fidell, 2007).

To aid in the interpretation of initial results, orthogonal rotation, specifically the Promax rotation, was used. The decision regarding the number of variables (factors) to be retained was based on the Guttman-Kaiser eigenvalue's greater-than-one rule (K1 rule), together with the scree plot (with specific reference to the shape of the curve) and lastly the Monte Carlo Principal component analysis (PCA) for parallel analysis. Meyers et al. (2013) indicated that a guide for variance accounted for by the factor needs to meet the lower limit of $50 \%$. The Cronbach's alpha coefficient was determined taking into consideration the fact that the general rule according to Nunnally and Bernstein (1994) is $\alpha>0.70$.

\section{Confirmatory factor analysis}

To operationalise this construct definition of the global (or unidimensional) construct, namely, servant leadership, a CFA was conducted. To assess the model fit, several fit indexes were used, including comparative fit index (CFI), root mean square error of approximation (RMSEA), chisquare $\left(\chi^{2}\right)$ and the ratio of the differences in chi-square to the 
differences in degrees of freedom $\left(\chi^{2} / d f\right)$. Given that there is no one acceptable cut-off value for what constitutes an adequate fit, it was decided to evaluate and recommend the model. The CFA index values, recommended by Byrne (2010), are 0.90 for CFI, an RMSEA value of 0.05 and in terms of the $\chi^{2} / d f$, a ratio of less than 5.00 . The option to use only these indexes was supported by Cheung and Rensvold (2002), who regarded it as a suitable indication of good fit.

\section{Validity assessment}

Convergent validity of the items was assessed by composite reliability (CR) and average variance extracted (AVE), with critical values of $>0.70$ and $<0.50$, respectively. The discriminant validity was determined by comparing AVE with Maximum Shared Variance (MSV). Proof of discriminant validly would be apparent if MSV < AVE and the Average Shared Variance (ASV) < AVE (Hair et al., 2010).

An elementary cross-validation assessment to determine invariance between private and public sectors, as well as between respondents in managerial and non-managerial positions, was also performed. The rationale for this step was to assess the possibility of invariance, which is regarded to be a prerequisite for meaningful interpretations and valid cross-group comparisons. It is important that items and constructs are understood and interpreted in the same way across different samples; the variance in the observed score differences between groups should not be a result of group membership but of the construct being measured. This was operationalised by conducting CFA for each group separately to test for invariance (Van de Schoot, Lugtig, \& Hox, 2012). The goodness-of-fit indexes were used to assess measurement invariance, as recommended by Cheung and Rensvold (2002). Owing to the fact that the scope of this study is not primarily about the nature of the measurement differences between groups but merely about the accurate measurement of the construct across two sets of samples (chosen arbitrarily), the following parameters were applied: Firstly, an inspection of the difference in the overall fit indexes, with difference in CFI and RMSEA, should be less than 0.02 and 0.03 , respectively - specifically for large samples (Rutkowski \& Svetina, 2014). It should further be mentioned that the fit indexes of both groups should be acceptable as minimum fit criteria. Secondly, difference in the Tucker-Lewis Index (TLI) should be less than or equal to 0.05 (Cheung \& Rensvold, 2002). Thirdly, there should be a small, non-significant difference in the Expected CrossValidation Index (ECVI) values when the groups are compared with one another (Milfont \& Fischer, 2010).

Information on convergent validity was created by calculating the correlation between SLQ7 and several other measures that were measured in a similar manner as part of the overall research project. It was hypothesised, supported by previous studies and literature, that servant leadership is related to other leadership styles that are also based on work relationships, leader behaviour or leadership style approaches, such as authentic leadership (Neider \& Schriesheim, 2011), Leader-member exchange (Liden \& Maslyn, 1998) and Afrocentric or Ubuntu leadership (Grobler \& Singh, 2018). It was further hypothesised that servant leadership would have a positive impact on organisational behaviour, namely, organisational identification (Mael \& Ashforth, 1992), psychological empowerment (Spreitzer, 1995), person-organisational fit, including supplementary fit or indirect fit (organisational fit as values congruence) and complementary fit or direct fit (needs-supplies fit and demand) (Cable \& DeRue, 2002; Grobler, 2016), work locus of control (Spector, 1988) and an employee's turnover intention (Brashear, Boles, Brooks, \& Bellenger, 2003).

A correlation value of 0.40 is regarded to be an indication of convergence, with a value of 0.50 and higher as a clear sign of convergence (Cohen, Swerdlik, \& Sturman, 2013). These are often referred to as heterotrait-monomethod (HTMM) coefficients and entail correlations between measures of different traits being furnished by the same method of measurement.

\section{Ethical consideration}

Ethical clearance was obtained from the University of South Africa's School of Business Leadership Research Ethics Review Committee on 15 March 2017 (ethical clearance reference number: 2017_SBL_002_CA), which includes permission from each organisation and consent of all the participants.

\section{Results}

Results of the statistical procedures mentioned in the previous section are discussed now. To determine the construct validity and construct equivalence of SLQ7, an EFA was conducted, as advocated by Nunnally and Bernstein (1994), who regarded it as an appropriate technique for crosscultural studies. The EFA was conducted on SLQ7 items.

A relatively large sample size contributed to an adequate variable-to-respondent ratio (252:1). The value of the KMO measure of sampling adequacy was 0.90, above the recommended value of 0.60 , and Bartlett's test of sphericity was significant $\left(\chi^{2}(21)=5638.54, p<0.001\right)$, supporting the strategy to conduct an EFA.

The Guttman-Kaiser K1 rule was used in conjunction with the scree plot to determine a number of factors. The results of the Kaiser's criterion, as determined by PCA, are reported in Table 2 .

TABLE 2: Eigenvalues close to or larger than one and explanation of variance.

\begin{tabular}{|c|c|c|c|c|c|c|c|}
\hline \multirow[t]{2}{*}{ Number } & \multicolumn{3}{|c|}{ Initial eigenvalues } & \multicolumn{3}{|c|}{ Extraction sums of squared loadings } & \multirow{2}{*}{$\frac{\text { Rotation sums of squared loadings }}{\text { Total }}$} \\
\hline & Total & Variance (\%) & Cumulative (\%) & Total & Variance $(\%)$ & Cumulative (\%) & \\
\hline 1 & 4.14 & 59.15 & 59.15 & 4.14 & 59.15 & 59.15 & 4.14 \\
\hline 2 & 0.70 & 9.98 & 69.14 & - & - & - & 0.70 \\
\hline
\end{tabular}


The factor solution with eigenvalues larger than 1 , as reported in Table 2, consists of one factor, with the closest value to 1 being 0.70 . The total variance explained is close to $60 \%$. Cattell's scree test, which is aimed at retaining the components (factors) before the break (elbow rule), was performed and the results are reported in Figure 1.

The interpretation of the scree plot depicted in Figure 1 indicates that there is clearly one strong factor, as the elbow flattens off after the first component. The interpretation of the scree plot is, however, hampered by the fact that the scree plot as well as the $\mathrm{K} 1$ rule is often regarded as being too conservative as measures to determine the exact number of factors (Pallant, 2013).

Subsequently, a more stringent technique, namely, the Monte Carlo parallel analysis simulation technique was performed. The purpose of the Monte Carlo parallel analysis is to determine the number of factors that account for more variance than the components derived from random data; the results are reported in Table 3.

The eigenvalues obtained from the actual data (4.14 and 0.70 for components 1 and 2, respectively) were compared with

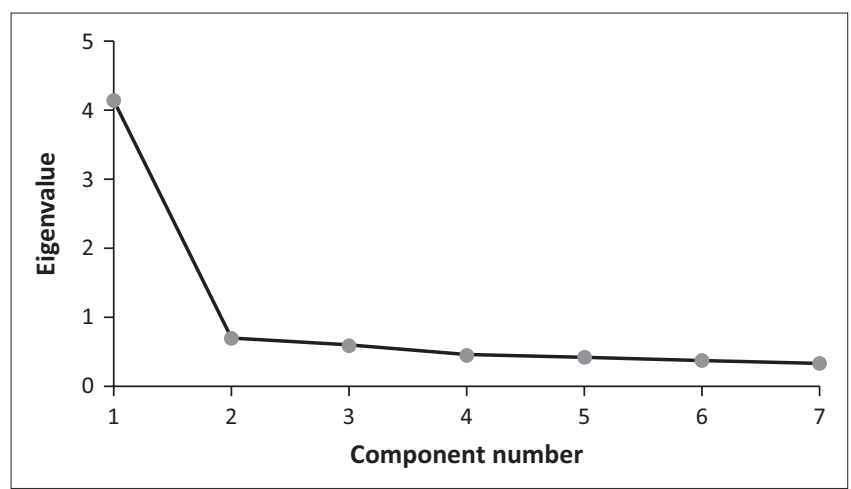

FIGURE 1: Cattell's scree plot.

TABLE 3: Results of the Monte Carlo parallel analysis.

\begin{tabular}{lccc}
\hline $\begin{array}{l}\text { Component } \\
\text { number }\end{array}$ & $\begin{array}{c}\text { Actual eigenvalues } \\
\text { from PCA }\end{array}$ & $\begin{array}{c}\text { Criterion value from } \\
\text { parallel analysis }\end{array}$ & Decision \\
\hline 1 & 4.14 & 1.08 & Accept \\
2 & 0.70 & 1.05 & Reject \\
\hline
\end{tabular}

PCA, Principal component analysis. the eigenvalues obtained from the random data (1.08 and 1.05 , respectively). The actual eigenvalues from the PCA of the actual data were greater than the eigenvalues from the random data for component 1 . The results of the Monte Carlo parallel analysis thus suggest a one-component (factor) model, supporting the $\mathrm{K} 1$ rule and the scree plot. The results of correlational analysis (Pearson correlation) between items, from now on referred to as the SLQ7 items, are reported in Table 4.

The correlations between the items were larger than 0.40 , ranging between 0.41 and 0.61 . Multicollinearity (tolerance and variance inflation factor [VIF]) of the items were determined (with the main construct as the dependent variable) to test a possible inflation of reliability coefficient. Tolerance is an indicator of the amount of variance not explained by other independent variables (in this case, item) in the model and should preferably be larger than 0.10 . Variance inflation factor, on the other hand, is the inverse of tolerance and values should be below 10 . No violation of collinearity was found.

The mean scores of all the items are relatively high (ranging from 3.94 to 5.11 on a seven-point Likert scale). All items reported negative values of skewness, ranging between -0.89 and -0.11 . This is an indication of the fact that the distribution in general has relatively few small values and tails off to the left. The kurtosis value ranged from 1.05 to 0.10 . The skewness and kurtosis values for all factors do not exceed the critical values of 2.00 and 7.00, respectively, which is an indication that the data are normally distributed (West, Finch, \& Curran, 1995). The communalities of the items are relatively high, ranging between 0.44 and 0.68 .

The descriptive statistics, the internal consistency as well as the convergent and discriminant validity of servant leadership as a global or unidimensional construct are reported in Table 5 .

The mean score for the construct servant leadership is 4.57 $(\mathrm{SD}=1.32)$, and the data did not violate the assumption of normality with a skewness value of -0.46 and kurtosis of -0.38 . The Cronbach's alpha coefficient was 0.88 (meeting

TABLE 4: Correlations (Pearson's) between the items of 7-item servant leadership questionnaire as well as the descriptive statistics and communalities of the items.

\begin{tabular}{|c|c|c|c|c|c|c|c|c|c|}
\hline & Tolerance & VIF & $\mathrm{SLQ}^{1}$ & $\mathrm{SLQ}^{2}$ & $\mathrm{SLQ}^{3}$ & $\mathrm{SLQ}^{4}$ & $\mathrm{SLQ}^{5}$ & $S L^{6}$ & SLQ $^{7}$ \\
\hline$\overline{\mathrm{SLQ}^{1}}$ & 1.80 & 0.55 & 1.00 & - & - & - & - & - & - \\
\hline $\mathrm{SLQ}^{2}$ & 2.30 & 0.43 & 0.61 & 1.00 & - & - & - & - & - \\
\hline $\mathrm{SLQ}^{3}$ & 1.98 & 0.51 & 0.53 & 0.60 & 1.00 & - & - & - & - \\
\hline $\mathrm{SLQ}^{4}$ & 1.91 & 0.52 & 0.48 & 0.57 & 0.55 & 1.00 & - & - & - \\
\hline $\mathrm{SLQ}^{5}$ & 2.18 & 0.46 & 0.46 & 0.60 & 0.60 & 0.61 & 1.00 & - & - \\
\hline $\mathrm{SLQ}^{6}$ & 1.89 & 0.53 & 0.45 & 0.55 & 0.49 & 0.50 & 0.56 & 1.00 & \\
\hline $\mathrm{SLQ}^{7}$ & 1.64 & 0.61 & 0.44 & 0.47 & 0.41 & 0.44 & 0.47 & 0.57 & 1.00 \\
\hline \multirow{5}{*}{$\begin{array}{l}\text { Descriptive } \\
\text { statistics }\end{array}$} & - & Mean & 5.11 & 4.52 & 4.34 & 4.22 & 3.94 & 4.81 & 5.03 \\
\hline & - & SD & 1.57 & 1.75 & 1.89 & 1.73 & 1.69 & 1.68 & 1.73 \\
\hline & - & Skewness & -0.89 & -0.46 & -0.32 & -0.21 & -0.11 & -0.66 & -0.68 \\
\hline & - & Kurtosis & 0.10 & -0.76 & -1.05 & -0.82 & -0.78 & -0.46 & -0.48 \\
\hline & - & Communality & 0.54 & 0.68 & 0.61 & 0.60 & 0.65 & 0.58 & 0.44 \\
\hline
\end{tabular}

SLQ, servant leadership questionnaire; VIF, variance inflation factor; SD, standard deviation. 
TABLE 5: Descriptive statistics, Cronbach's alpha coefficient, and convergent and discriminant validity of the unidimensional construct and servant leadership.

\begin{tabular}{lc}
\hline Statistics & Servant leadership \\
\hline Mean & 4.57 \\
Standard deviation & 1.32 \\
Skewness & -0.46 \\
Kurtosis & -0.38 \\
Cronbach's alpha coefficient $(\alpha)$ & 0.88 \\
Composite reliability & 0.91 \\
Average variance extracted & 0.59 \\
Maximum shared variance & 0.37 \\
Average shared variance & 0.26 \\
\hline
\end{tabular}

the general requirement of 0.70 ). The convergent validity of the items was confirmed by CR with a critical value of $>0.70$. The AVE value was slightly higher than the critical value of 0.50 . The discriminant validity of the seven items was further determined by comparing AVE with MSV. Satisfactory discriminant validly was reported with MSV < AVE and ASV < AVE (Hair et al., 2010).

It was further deemed necessary to inspect the instrument for construct validity by conducting CFA. The results are reported in Table 6 in terms of respective fit indexes, more specifically CFI, RMSEA, chi-square and the ratio of the differences in chi-square to the differences in degrees of freedom.

In order to determine the validity of the instrument by using independent samples, two elementary cross-validation analyses were conducted. The rationale for this step is to assess the possibility of invariance between two sample groups. Firstly, the sample was split into sectors, namely, the private and public sectors. Five-hundred cases were randomly selected from each sector (from a total sample of private and public sectors comprising 831 and 915 cases, respectively). The results reported were $\chi^{2} / d f(9)=2.66$, $\mathrm{CFI}=0.99, \mathrm{TLI}=0.98, \mathrm{RMSEA}=0.06, \mathrm{ECVI}=0.12$ and $\chi^{2} / d f(9)=1.36$, CFI $=0.99$, TLI $=0.99$, RMSEA $=0.027$, $\mathrm{ECVI}=0.10$ for private and public sectors, respectively. The degree of invariance in terms of the likelihood ratio test was 1.30 (2.66-1.36), and TLI values were 0.98 and 0.97 , thus with a difference lower than the norm of 0.05 . The ECVI values for private and public sectors were 0.12 and 0.10 , respectively (difference $=0.02$, which is marginal).

In addition to the comparison of both sectors, possible invariance was assessed by splitting the sample into participants currently in managerial positions $(n=600)$ and in non-management positions $(n=1176)$. Five hundred cases were randomly selected from both sample groups. The results reported were $\chi^{2} / d f(9)=1.24, \mathrm{CFI}=0.99$, TLI $=0.99$, $\mathrm{RMSEA}=0.02, \mathrm{ECVI}=0.10$ and $\chi^{2} / d f(9)=2.46, \mathrm{CFI}=0.99$, $\mathrm{TLI}=0.98, \mathrm{RMSEA}=0.05, \mathrm{ECVI}=0.12$ for management and non-management groups, respectively. The degree of invariance in terms of the likelihood ratio test was 1.22 (2.46-1.24), and the difference between TLI values was 0.01 (0.99-0.98). Difference between ECVI values for the two groups was marginal (0.02). The cross-validation in both instances lends support to the notion of invariance.
In addition to CR, AVE, MSV and ASV that looked at convergent and discriminant validity in terms of SLQ7 items that loaded on the unidimensional factor, the convergent validity of the overall instrument was also determined. The convergent validity of servant leadership (as measured by SLQ7) was examined by means of HTMM coefficients, comparing servant leadership with a range of cognate constructs. Information on convergent validity was created by calculating correlation between SLQ7 and several other measures that formed part of the overall research project. These instruments and constructs were selected because of their hypothesised relationship with servant leadership. The instruments or constructs, all selected after inspection of their psychometric properties (all reported $\alpha>0.70$ ), are authentic leadership, LMX, Afrocentric or Ubuntu leadership (all relationalleadership constructs), organisationalidentification, psychological empowerment, person-organisational fit, internal work locus of control and turnover intention (all considered to be a result of servant leadership or the absence thereof). The Pearson's product moment correlations are reported in Table 7.

It is apparent that there was some degree of convergence after the correlations (all $p \leq 0.001$ ) given in Table 7 were

TABLE 6: Confirmatory factor analysis on the unidimensional construct - Servant leadership (all seven original items).

\begin{tabular}{lccccc}
\hline Structure & $\chi^{2}$ & $d f$ & $\chi^{2} / d f$ & CFI & RMSEA \\
\hline Unidimensional model $\dagger$ & 24.80 & 9 & 2.76 & 0.99 & 0.032 \\
\hline
\end{tabular}

Note: All chi-square values are significant at $p<0.001$.

$\mathrm{CFI}$, comparative fit index; RMSEA, root mean square error of approximation; EFA, exploratory factor analysis.

$\dagger$, All seven items as determined by the exploratory factor analysis.

The unidimensional or global factor model (all seven items), as determined by EFA, reported acceptable fit with $\chi^{2} / d f(9)=2.76, \mathrm{CFI}=0.99$ and RMSEA $=0.032$.

TABLE 7: Convergent validity of servant leadership (as measured by the sevenitem servant leadership questionnaire) through heterotrait-monomethod comparison.

\begin{tabular}{llc}
\hline Cognate constructs & & Servant leadership \\
\hline Leadership constructs & Authentic leadership (AL) & 0.75 \\
& - AL_self-awareness & 0.70 \\
& - AL_relational transparency & 0.69 \\
& - AL_internalised moral perspective & 0.64 \\
& - AL_balanced processing & 0.72 \\
& Leader member exchange (LMX) & 0.65 \\
& - LMX_affect & 0.59 \\
& - LMX_loyalty & 0.53 \\
& - LMX_contribution & 0.38 \\
& - LMX_professional respect & 0.57 \\
& Afrocentric or Ubuntu leadership & 0.61 \\
Organisational identification & 0.38 \\
behanisational & - PE_meaning & 0.32 \\
& - PE_competence & 0.23 \\
& - PE_self-determination & 0.29 \\
& - PE_impact & 0.36 \\
& Psychological empowerment (PE) & 0.39 \\
& Person-organisational fit (PoF) & 0.46 \\
• PoF_supplementary fit & 0.42 \\
• PoF_complementary fit & 0.41 \\
Turnover intention (negative construct) & -0.25 \\
Internal work locus of control & 0.23 \\
\hline & & \\
\hline
\end{tabular}

Note: All correlations are significant at $p \leq 0.001$ level (two-tailed). 
inspected. This was specifically true in terms of the hypothesised relationship between servant leadership and related leadership constructs. Authentic leadership (and its sub-factors) reported the highest correlations with servant leadership ( $r$-value ranging from 0.75 to 0.64 ). Leader-manager exchange (and its sub-factors, except contribution), as well as Afrocentric or Ubuntu leadership, reported correlations of higher than 0.50 with servant leadership, which was a clear indication of convergent validity.

Furthermore, it was found that servant leadership has a positive relationship with organisational identification, psychological empowerment, person-organisational fit, work locus of control (correlations range from 0.23 to 0.46 ) and a negative relationship (correlation of -0.25 ) with turnover intention. These results supported the notion of convergent validity of SLQ7.

\section{Discussion and conclusion}

Leadership, and specifically servant leadership, is a prominent issue in South Africa. Leaders are always confronted with the challenge of using their organisational influence for personal benefits and for the benefit of their followers. By adopting a servant leadership style, leaders would selflessly invest in their followers, which could have a positive impact on follower well-being, engagement and performance (Van Dierendonck \& Nuijten, 2011). The essence of servant leadership seems to be service to the good of the whole, and this primary intent - motivation drive - is what distinguishes servant leadership from other leadership styles. What essentially emerges from the servant leadership literature is that there is little consensus regarding the conceptualisation of servant leadership (Sun \& Wang, 2009), although the conceptualisation of the construct does not form part of this study. Hence, the purpose of this article was to assess SLQ7 in terms of its construct validity, and to cross validate it by utilising arbitrarily chosen, independent samples within the South African context.

This study supports the work carried out by the developers of SLQ7 in terms of the factorial composition of the instrument. Exploratory factor analysis, as well as CFA, yielded a onefactor solution, suggesting that servant leadership, as measured by SLQ7, is a unidimensional construct. The instrument (more specifically, its items) was assessed for possible multicollinearity, which might have affected the relatively high Cronbach's alpha coefficient $(\alpha=0.88)$. No violation of multicollinearity was found after inspecting tolerance and VIF values. The instrument (in terms of its items) was further found to have the necessary convergent validity, assessed by means of CR (0.91) and AVE (which was slightly above the critical value). The discriminant validity was assessed, comparing AVE with MSV and ASV and AVE. The instrument in terms of the seven items was found to have necessary convergent and discriminant validity.

Confirmatory factor analysis was conducted on a unidimensional construct. It yielded highly acceptable results when the fit indexes were inspected and interpreted. The instrument was further cross validated using two sets of sample groups, namely the private and public sectors, as well as respondents in managerial and non-managerial positions. This was conducted to ensure that the results obtained from the instruments would be that of inherent nature of the construct being measured (servant leadership) and not because of membership of one of the four sample groups. No invariance was found, which suggests that the instrument can be used, regardless of group membership.

The convergent validity of servant leadership, as measured by SLQ7, was further assessed by comparing it statistically with hypothesised cognate constructs This includes other leadership styles (authentic leadership, LMX and Afrocentric or Ubuntu leadership) as well as organisational behaviour constructs (organisational identification, psychological empowerment, person-organisational fit, internal work locus of control as well as turnover intention). High (statistically significant) correlations were reported between servant leadership and the other leadership measurements, suggesting convergent validity of the instrument. Relatively strong correlations were reported between servant leadership and the organisational behaviour constructs, which is an indication of the scientific and practical value of the instrument. It could be used with confidence (and ethically) in the study of servant leadership and the relationship it has with various organisational behaviour phenomena. The results of this research could be used in terms of leadership training and general organisational development intervention design.

\section{Practical/managerial implications and the contribution of the study}

This study's contribution to science, practice and the community is based on the importance of the servant leadership construct when leading people, specifically in the South African (and African) context. Based on developments within the South African context, a high premium is placed on servant leadership and future research related to servant leadership. Subsequently, there is a need for a short and valid measure of servant leadership, as postulated by Credé et al. (2012). This study has found that the SLQ7, as developed by Liden et al. (2015), is suitable to be used within the South African context, with servant leadership being measured as a unidimensional construct. Servant leadership has also been found to have a statistical relationship with other organisational behaviour constructs, thus making it suitable for studying employee attitudes and behaviour (by academics, leadership scholars, human resource and organisational development practitioners) in relation to servant leadership across various organisational settings. The contribution to the community is in terms of the enhancement of servant leadership through measurement and monitoring of its existence and magnitude in organisations. This could further be transferred into other non-organisational settings and the society. This would be 
congruent with the African leadership viewpoint that subscribes to the altruistic mindset of followers first.

\section{Limitations of the study and suggestions for future research}

The limitations of this study are mainly attributed to the methodology employed. Self-reporting serves as the basis of SLQ7, and this might lead to method bias. One measure utilised in this study to limit this kind of bias is a thorough and standardised briefing of the respondents with regard to anonymity as well as confidentiality. The wording and vocabulary used in SLQ7 (without adapting it to the South African [multi-lingual] context) may be listed as a further possible limitation. Because the SLQ7 is an imported instrument, culture-specific or emic aspects of a construct would remain hidden and lead to the underrepresentation of the unique aspects of South African culture. A further limitation of this study is the drawback of a cross-sectional design, which could have increased the extent of relationship between the three components artificially, resulting in little knowledge in terms of how the process unfolds over time and on the direction of causality.

As this was an etic (studying an existing foreign instrument within a different context), exploratory and quantitative study, it is suggested that the possibility of validating the instrument (and construct) by means of the assessment of actual behaviour or intentions of leaders (instead of follower perceptions of servant leader behaviour) be investigated by applying quantitative methods. Lastly, the construct of servant leadership could be studied from an etic-emic position, with the use of these results (as etic evidence) and the development of new and context-specific items (from an emic-African perspective) employed to test the construct in further studies.

\section{Acknowledgements}

The authors would like to than the participants for taking part in the research.

\section{Competing interests}

The authors have declared that no competing interests exist.

\section{Authors' contributions}

All authors contributed equally to this work.

\section{Funding information}

This research received no specific grant from any funding agency in the public, commercial or not-for-profit sectors.

\section{Data availability statement}

Data sharing is not applicable to this article as no new data were created or analysed in this study.

\section{Disclaimer}

The views and opinions expressed in this article are those of the authors and do not necessarily reflect the official policy or position of any affiliated agency of the authors.

\section{References}

Asante, M.K. (1988). Afrocentricity. Trenton, NJ: Africa World Press.

Avey, J.B., Wernsing, T.A., \& Palanski, M.E. (2012). Exploring the process of ethical leadership: The mediating role of employee voice and psychological ownership. Journal of Business Ethics, 107(1), 21-34. https://doi.org/10.1007/s10551-012$1298-2$

Banks, G.C., McCauley, K.D., Gardner, W.L., \& Guler, C.E. (2016). A meta-analytic review of authentic and transformational leadership: A test for redundancy. The Leadership Quarterly, 27, 634-652. https://doi.org/10.1016/j.leaqua.2016.02.006

Barbuto, J.E. Jr., \& Wheeler, D.W. (2006). Scale development and construct clarification of servant leadership. Group \& Organization Management, 31(3), 300-326. https://doi.org/10.1177/1059601106287091

Bass, B.M. (2000). The future of leadership in the learning organization. Journal of Leadership Studies, 7(3), 18-38. https://doi.org/10.1177/107179190000700302

Block, P. (1993). Stewardship: Choosing service over self-interest. San Francisco, CA Berrett-Koehler.

Brashear, T., Boles, J.S., Brooks, C., \& Bellenger, D.N. (2003). Trust-building processes and outcomes in sales manager-salesperson relationships: An empirical test and comparison. Journal of the Academy of Marketing Science, 31(2), 189-200. https://doi.org/10.1177/0092070302250902

Braun, S., \& Nieberle, K.W.A.M. (2017). Authentic leadership extends beyond work: A multi-level model of work-family conflict and enrichment. Leadership Quarterly, 28, 780-797. https://doi.org/10.1016/j.leaqua.2017.04.003

Buchen, I.H. (1998). Servant leadership: A model for future faculty and future institutions. The Journal of Leadership Studies, 5(1), 125-134. https://doi.org/ 10.1177/107179199800500111

Byrne, B. (2010). Structural equation modeling with AMOS: Basic concepts, applications, and programming. Mahwah, NJ: Lawrence Erlbaum.

Cable, D.M., \& DeRue, D.S. (2002). The convergent and discriminant validity of subjective fit perceptions. Journal of Applied Psychology, 87, 875-884. https:// doi.org/10.1037/0021-9010.87.5.875

Chawane, M. (2016). The development of Afrocentricity: A historical survey. Yesterday \& Today, 16, 78-99. https://doi.org/10.17159/2223-0386/2016/n16a5

Cheung, G.W., \& Rensvold, R.B. (2002). Evaluating goodness-of-fit indexes for testing measurement invariance. Structural Equation Modeling. A Multidisciplinary Journal, 9(2), 233-255. https://doi.org/10.1207/S15328007SEM0902_5

Cohen, R.J., Swerdlik, M., \& Sturman, E. (2013). Psychological testing and assessment (8th edn.). New York: McGraw-Hill.

Credé, M., Harms, P., Niehorster, S., \& Gaye-Valentine, A. (2012) An evaluation of the consequences of using short measures of the big five personality traits. Journal of Personality and Social Psychology, 102, 874-888. https://doi.org/10.1037/ a0027403

Crippen, C.L. (2004). Pioneer women in Manitoba: Evidence of servant-leadership. Journal of Women in Educational Leadership, 2(4), 257-271.

Crippen, C.L., \& Wallin, D. (2008). First conversations with Manitoba superintendents: Talking their walk. Alberta Journal of Educational Research, 54(2), 147-160.

Dansereau, F., Graen, G., \& Haga, W.J. (1975). A vertical dyad linkage approach to leadership within formal organizations: A longitudinal investigation of the rolemaking process. Organizational Behavior and Human Performance, 13, 46-78. https://doi.org/10.1016/0030-5073(75)90005-7

Dennis, R.S., \& Bocarnea, M. (2005). Development of the servant leadership assessment instrument. Leadership \& Organization Development Journal, 26(8), 600-615. https://doi.org/10.1108/01437730510633692

Dennis, R.S., Kinzler-Norheim, L., \& Bocarnea, M. (2010). Servant leadership theory: Development of the servant leadership assessment instrument. Leadership \& Organization Development Journal, 32(4), 411-425. https://doi.org/10.1057/ 9780230299184_14

Diamond, M.A. (2016). Discovering organizational identity: Dynamics of relational attachment. Columbia, MO: University of Missouri Press.

Early, G., Moses, W.J., Wilson, L., \& Lefkowitz, M.R. (1994). Symposium: Historical roots of Afrocentrism. Academic Questions, 7(2), 44-54. https://doi.org/10.1007/ BF02683155

Ebener, D.R., \& O'Connell, D.J. (2010). How might servant leadership work? Nonprofit Management and Leadership, 20(3), 315-335. https://doi.org/10.1002/nml.256

Ehrhart, M.G. (2004). Leadership and procedural justice climate as antecedents of unit level organizational citizenship behavior. Personnel Psychology, 57(1), 61-94. https://doi.org/10.1111/j.1744-6570.2004.tb02484.x

Engle, E.M., \& Lord, R.G. (1997). Implicit theories, self-schemas, and leader-member exchange. Academy of Management Journal, 40(4), 988-1010. https://doi.org/ 10.2307/256956

Farling, M.L., Stone, G.A., \& Winston, B.E. (1999). Servant leadership: Setting the stage for empirical research. Journal of Leadership Studies, 6, 49-672. https://doi. org/10.1177/107179199900600104 
Fourie, W., Van der Merwe, S.C., \& Van der Merwe, B. (2017). Sixty years of research on leadership in Africa: A review of the literature. Leadership, 13(2), 222-251. on leadership in Africa: A review of the lite
https://doi.org/10.1177/1742715015580665

Geldenhuys, C.A., \& Veldsman, T.H. (2010). A change navigation-based, scenario planning process within a developing world context from an Afrocentric leadership perspective. SA Journal of Human Resource Management, 9(1), 1-17. https://doi. org/10.4102/sajhrm.v9i1.265

Graen, G.B., \& Uhl-Bien, M. (1995). Relationship-based approach to leadership Development of the leader-member exchange (LMX) theory of leadership ove 25 years. Leadership Quarterly, 6, 219-247. https://doi.org/10.1016/10489843(95)90036-5

Graham, J. (1991). Servant leadership in organizations: Inspirational and moral. Leadership Quarterly, 2(2), 105-119. https://doi.org/10.1016/1048-9843(91)90025-W

Greenleaf, R.K. (1977). Servant leadership: A journey into the nature of legitimate power and greatness. Mahwah, NJ: Paulist Press.

Grobler, A. (2016). Person-organisational fit: A revised structural configuration Journal of Applied Business Research, 32(5), 1419-1434. https://doi.org/ Journal of Applied Busine
$10.19030 /$ jabr.v32i5.9769

Grobler, A., \& Singh, M. (2018). Leadership in Southern Africa: A regional Afrocentric hierarchical taxonomy. Insight on Africa, 10(2), 1-25. https://doi.org/10.1177/ 0975087818772236

Hair, J.F., Black, W.C., Babin, B.J., \& Anderson, R.E. (2010). Multivariate data analysis A global perspective (7th edn.). Boston, MA: Pearson.

IBM Corp. (2017). IBM SPSS statistics for Windows, version 25.0. Armonk, NY: IBM Corp.

Ilies, R., Morgeson, F.P., \& Nahrgang, J.D. (2005). Authentic leadership and eudaemonic well-being: Understanding leader-follower outcomes. The Leadership Quarterly, 16, 373-394. https://doi.org/10.1016/j.leaqua.2005.03.002

llies, R., Nahrgang, J.D., \& Morgeson, F.P. (2007). Leader-member exchange and citizenship behaviors: A meta-analysis. Journal of Applied Psychology, 92(1) citizenship behaviors: A meta-analysis. Journal of Appl
269-277. https://doi.org/10.1037/0021-9010.92.1.269

Laschinger, H.K.S., \& Fida, R. (2014). New nurses burnout and workplace wellbeing: The influence of authentic leadership and psychological capital. Burnout Research, 1, 19-28. https://doi.org/10.1016/j.burn.2014.03.002

Laub, J.A. (1999). Assessing the servant organization: Development of the organizational leadership assessment (OLA) instrument. Dissertation Abstracts International, 60(2), 308A.

Laub, J.A. (2004). Defining servant leadership: A recommended typology for servant leadership studies. In Proceedings of servant leadership research roundtable, School of Leadership Studies (pp. 1-12), Virginia Beach, VA: Regent University. August 2-3, 2004. Retrieved from http://www.strandtheory.org/images/Laub_Defining_Servant_Leadership.pdf

Liden, R.C., \& Maslyn, J.M. (1998). Multidimensionality of leader-member exchange: An empirical assessment through scale development. Journal of Management, 24, 43-72. https://doi.org/10.1016/S0149-2063(99)80053-1

Liden, R.C., Wayne, S.J., Meuser, J.D., Hu, J., Wu, J., \& Liao, C. (2015). Servant leadership: Validation of a short form of the SL-28. Leadership Quarterly, 26, 254-269. https://doi.org/10.1016/j.leaqua.2014.12.002

Liden, R.C., Wayne, S.J., Zhao, H., \& Henderson, D. (2008). Servant leadership: Development of a multidimensional measure and multi-level assessment. Leadership Quarterly, 19, 161-177.

Long, S.D. (2008). The perverse organisation and its deadly sins. London: Karnac.

Lunenburg, F.C. (2010). Leader-member exchange theory: Another perspective on the leadership. International Journal of Management, Business, and Administration, 13(1), 1-5.

Mael, F., \& Ashforth, B.E. (1992). Alumni and their alma mater: A partial test of the reformulated model of organizational identification. Journal of Organizational Behavior, 13(2), 103-123. https://doi.org/10.1002/job.4030130202

Mahembe, B., \& Engelbrecht, A.S. (2013). A confirmatory factor analytical study of a servant leadership measure in South Africa. SA Journal of Industrial Psychology/ SA Tydskrifvir Bedryfsielkunde, 39(2), Art. \#1127, 1-8. https://doi.org/10.4102/ sajip.v39i2.1127

Mbigi, L. (2000). In search of the African business renaissance: An African cultural perspective. Johannesburg: Knowledge Resources.

Mbiti, J. (1989). African religions and philosophy (2nd edn.). Oxford: Heinemann Educational.

Meyers, L.S., Gamst, G., \& Guarino, A.J. (2013). Applied multivariate research. Design and interpretation (2nd edn.). Thousand Oaks, CA: Sage.

Milfont, T.L., \& Fischer, R. (2010). Testing measurement invariance across groups: Applications in cross-cultural research. International Journal of Psychological Research, 3(1), 111-121. https://doi.org/10.21500/20112084.857

Mitonga-Monga, J., Flotman, A.P., \& Cilliers, F. (2016). Workplace ethics culture and work engagement: The mediating effect of ethical leadership in a developing world context. Journal of Psychology in Africa, 26(4), 326-333. https://doi.org/10 $.1080 / 14330237.2016 .1208928$

Mulemfo, M.M. (2000). Thabo Mbeki and the African renaissance. Pretoria: Actua Press.

Neider, L.L., \& Schriesheim, C.A. 2011. The authentic leadership inventory (ALI) Development and empirical tests. Leadership Quarterly, 22, 1146-1164. https:// doi.org/10.1016/j.leaqua.2011.09.008

Ngambi, H.C. (2004). African leadership: Lessons from the chiefs. In T.N.A. Meyer \& I. Boninelli (Eds.), Conversations in leadership (pp. 107-132). Randburg: Knowres.

Nkomo, S.M. (2011). A post-colonial and anti-colonial reading of 'African' leadership and management in organization studies: Tensions, contradictions and possibilities. Organization, 18(3), 365-386. https://doi.org/10.1177/1350508411398731
Nunnally, J.C., \& Bernstein, I.H. (1994). Psychometric theory (3rd edn.). New York, NY: McGraw-Hill.

Page, D., \& Wong. P. (2000). A conceptual framework for measuring servant leadership. In S. Adjibolosoo (Ed.), The human factor in shaping the course of history and development. Lanham, MD: University Press of America.

Pallant, J. (2013). SPSS survival manual: A step by step guide to data analysis using (4th edn.). London: Open University Press.

Parris, D.L., \& Peachey, J.W. (2013). A systematic literature review of servant leadership theory in organizational contexts. Journal of Business Ethics, 113, 377-393. https://doi.org/10.1007/s10551-012-1322-6

Patterson, K. (2003). Servant leadership: A theoretical model. Unpublished doctoral dissertation, Regent University, Graduate School of Business.

Peterson, S.J., Galvin, B.B., \& Lange, D. (2012). CEO servant leadership: Exploring executive characteristics and firm performance. Journal of Management and Organisation, 21(3), 1-28.

Ragnarsson, S., Kristjansdottir, E.S., \& Gunnarsdottir, S. (2018). To be accountable while showing care: The lived experience of people in a Servant Leadership Organisation. Sage Open, 8(3, July-September), 1-12.

Rutkowski, L., \& Svetina, D. (2014). Assessing the hypothesis of measurement invariance in the context of large-scale. International Surveys. Educational and Psychological Measurement, 74(1), 31-57. https://doi.org/10.1177/ 0013164413498257

Savage-Austin, A., \& Honeycutt, A. (2011). Servant leadership: A phenomenological study of practices, experiences, organizational effectiveness, and barriers. Journa of Business \& Economics Research, 9(1), 49-54. https://doi.org/10.19030/jber. v9i1.939

Sendjaya, S., \& Sarros, J. (2002). Servant leadership: Its origin, development, and application in organizations. Journal of Leadership and Organizational Studies, 9(2), 57-64. https://doi.org/10.1177/107179190200900205

Sendjaya, S. (2003). Development and validation of servant leadership behavior scale. Retrieved from http://www.regent.edu/acad/sls/publications/conference_ proceedings/servant_leadership_roundtable/2003pdf/sendjaya_development_ validation.pdf

Sendjaya, S., Sarros, J.C., \& Santora, J.C. (2008). Defining and measuring servant leadership behaviour in organizations. Journal of Management Studies, 45(2), 402-424. https://doi.org/10.1111/j.1467-6486.2007.00761.x

Sher, M. (2010). Corruption: Aberration or an inevitable part of the human condition? Insights from a Tavistock approach. Organisational \& Social Dynamics, 10(1), 40-55.

Spears, L.C. (1998). Insights on leadership: Service, stewardship, spirit and servantleadership. New York, NY: John Wiley \& Sons.

Spears, L.C. (2002). Introduction: Tracing the past, present and future of servantleadership. In L.C. Spears (Ed.), Focus on leadership (pp. 1-18). New York: Wiley.

Spears, L.C. (2010). The character and servant leadership: Ten characteristics of effective, caring leaders. Journal of Virtues \& Leadership, 1(1), 25-30.

Spector, P.E. (1988). Development of the work locus of control scale. Journal of Occupational Psychology, 61,219-230. https://doi.org/10.1111/j.2044-8325.1988. tb00470.x

Spreitzer, G.M. (1995). Psychological empowerment in the workplace: Dimensions, measurement, and validation. Academy of Management Journal, 38(5), 1442-1465. https://doi.org/10.5465/256865

Steffens, N.K., Mols, F., Haslam, S.A., \& Okimoto, T.G. (2016). True to what we stand for: Championing collective interests as a path to authentic leadership. Leadership Quarterly, 27, 726-744. https://doi.org/10.1016/j.leaqua.2016.04.004

Sturm, B.A. (2009). Principles of servant-leadership in community health nursing Management issues and behaviors discovered in ethnographic research. Home Health Care Management \& Practice, 21(2), 82-89. https://doi.org/10.1177/ 1084822308318187

Sun, J.M., \& Wang, B. (2009). Servant leadership in China: Conceptualisation and measurement. Advances in Global Leadership, 5, 321-344. https://doi.org/ 10.1108/S1535-1203(2009)0000005017

Tabachnick, B.G., \& Fidell, L.S. (2007). Using multivariate statistics (5th edn.). Boston, MA: Pearson.

Thao, N.P.H., \& Kang, S.-W. (2020). When servant leaders inspire followers to become organisational citizens: Empirical evidence from Vietnam. Sage Open, 10(1, January-March), 1-12.

Van de Schoot, R., Lugtig, P., \& Hox, J. (2012). A checklist for testing measurement invariance. European Journal of Developmental Psychology, 9(4), 486-492. $\mathrm{https}: / /$ doi.org/10.1080/17405629.2012.686740

Van Dierendonck, D. (2011). Servant leadership: A review and syntheses. Journal of Management, 27(4), 1228-1261. https://doi.org/10.1177/0149206310380462

Van Dierendonck, D., \& Nuijten, I. (2011). The servant-leadership survey (SLQS) Development and validation of a multidimensional measure. Journal of Business and Psychology, 26(3), 249-267. https://doi.org/10.1007/s10869-010-9194-1

Van Dierendonck, D., Stam, D., Boersma, P., De Windt, N., \& Alkema, J. (2014). Same difference? Exploring the differential mechanisms linking servant leadership and transformational leadership to follower outcomes. Leadership Quarterly, 25, 544-562.

Van Rensburg, G. (2013). The leadership challenge in Africa. Pretoria: Van Schaik.

Vansina, L.S. (2014). Are we, social scientists, neglecting humanness in organisations? A manifesto. Organisational and Social Dynamics, 14(2), 379-398. 
Walumbwa, F.O., Avolio, B.J., Gardner, W.L., Wernsing, T.S., \& Peterson, S.J. (2008) Authentic leadership: Development and validation of a theory-based measure.
Journal of Management, 34,89-126. https://doi.org/10.1177/0149206307308913

Walumbwa, F.O., Hartnell, C.A., \& Oke, A. (2010). Servant leadership, procedural justice climate, service climate, employee attitudes, and organizational citizenship behavior: A cross-level investigation. Journal of Applied Psychology, 95(3), 517-529. https://doi.org/10.1037/a0018867

Walumbwa, F.O., \& Schaubroeck, J. (2009). Leader personality traits and employee voice behaviour: Mediating roles of ethical leadership and work group psychological safety. Journal of Applied Psychology, 94(5), 1275-1286. https://doi.org/10.1037/a0015848
West, S.G., Finch, J.F., \& Curran, P.J. (1995). Structural equation models with nonnormal variables: Problems and remedies. In R.H. Hoyle (Ed.), Structural equation modelling: Concepts, issues, and applications (pp. 159-176). Thousand Oaks, CA: Sage.

Wong, P.T.P., \& Page, D. (2003). Servant leadership: An opponent process model and the revised servant leadership profile. Unpublished paper. Retrieved June 25, 2019, from http://www.regent.edu

Yawson, R. (2017). Leadership development in South Africa. In A. Ardichvili \& K. Diran (Eds.), Leadership development in emerging market economies (pp. 93-109). New York: Palgrave Macmillan. 